\title{
能動機構と多次元ビュー生成に基づくバッチ製造情報 管理システムの実現*
}

高田 秀志**.島川 博光** . 浅野 義智***. 竹垣 盛一**

\section{A Batch Manufacturing Information Management System Based on Active Mechanism and Multidimensional View Generation*}

\author{
Hideyuki TAKadA**, Hiromitsu ShimaKawa**, Yoshitomo Asano*** \\ and Morikazu TAKEGAKI**
}

\begin{abstract}
In batch manufacturing information management systems, software productivity is a big problem because it is difficult to provide commonly-utilized software layer due to differences of plant facilities and production processes among target plants. In this paper, we present a model of a batch tracing mechanism and a view generation mechanism which can be utilized as a software layer organizing a batch manufacturing information management system. In addition, we confirmed that an application of this software layer for a model plant can be performed in short time and run-time performance is good enough for a practical use.
\end{abstract}

\section{1. まえがき}

近年，生産現場へのパソコンなどの汎用計算機の普及 に伴って，製造管理システムの高機能化が求められてい る. 本論文で対象とする製造情報管理システムは，食品 や化学製品など, 製造分野では最も一般的なバッチプロ セスを対象とする. バッチプロセスは, バッチと呼ばれる 単位に区切って製品を製造する。バッチプロセスにおけ る製造情報管理に最も求められる機能は, 製造設備から 周期的に収集される状態履歴データと，製造設備間を移 動するバッチとの関連付けである．たとえば，消費者か らの苦情や品質検査などの段階で製造物に不具合が見つ かった場合，その製造過程においてどの製造設備で問題 があったかを分析するには, そのバッチが各製造設備に存 在していた時の状態履歴が必要である。このような機能 を実現するには, 計算機中でバッチプロセス内のバッチの

* 原稿受付 1996 年 10 月 3 日

** 三菱電機 (株) 産業システム研究所 Industrial Electronics \& Systems Lab., Mitsubishi Electric Corp.; Tsukaguchi-Honmachi 8-1-1, Amagasaki city, Hyogo 661 , JAPAN

*** 三菱電機（株）電力・産業システム事業所 Energy \& Industrial Systems Center, Mitsubishi Electric Corp.; Yadasaki-cho 1-1-2, Hyogo word, Kobe city, Hyogo 652 , JAPAN

Key Words: database, active mechanism, multidimensional view, manufacturing information management, batch processes.
動きを追跡してそれを履歴として格納し，プラントの操 作員には，着目されたバッチに関する情報を合成して提 供する機構が必要となる。このような機構を実現する際, 現状では, バッチプロセス内のバッチの動きや, デー夕 の利用形態が対象プラントごとに異なることから，バッ チの追跡機構やデー夕提供機構をすべて対象プラントご とに構築しており，ソフトウエアの生産性が非常に悪い.

この理由には, 以下に述べるバッチプロセス特有の性 質から，バッチ追跡機構やデー夕提供機構を複数の対象 プラント間で共通化し，モデル化することが進んでいな いことが挙げられる。まず，バッチプロセスの製造過程 においては，たとえば，複数の種類の液体を混合したり， 逆に複数の種類の液体に分離したりするなどのように， バッチを混合したり分割したりする過程が存在する。そ のため, 対象プラント間で共通のデー夕構造を決定しに くい.また, デー夕の利用形態も，連続プロセスなどにお ける帳票のようなものでは十分でなく，製造設備に着目 したり，バッチに着目したりといった多視点からの分析作 業を支援できるものでなくてはならない.しかし，この ようなデータの生成は, 対象プラントごとに異なるバッ チの流れに依存しているため, デー夕提供機構に含まれ るデータベースへの問合せ手順なども一般化するのが困 難である.

本論文では, バッチプロセスにおける製造情報管理シ 
ステムを構築するうえで必要となるバッチ追跡機構, お よび, デー夕提供機構について，それらを対象プラント 間で共通化するためのバッチ製造情報管理モデルと，そ れに基づいて構築したバッチ製造情報管理システムにつ いて述べる. 本システムは, 以下のような特徴を持つ.

・バッチを追跡するために，バッチプロセス内の製造 設備をバッチの混合や分割の形態によって 5 種類に 分類する.また，オブジェクト指向データモデルを 応用し, バッチの混合や分割をリンクによるポイン 夕操作だけで表現可能な製造情報管理データモデル に基づくバッチ追跡機構を提供する.

・バッチプロセスを「時間軸上でバッチが製造設備間を 移動する」ととらえ, データの利用形態として, 時 間・製造設備・バッチのそれぞれに着目した多次元 ビューを生成するデー夕提供機構を提供する.

・対象プラントごとに異なる収集データや設備構成, バッチの流れ等を, GUIにより指定可能な定義ツー ルを提供する.

以下, 2. では, バッチプロセスの概要とその製造情報 管理システムに要求される機能について述べる. 3. では, 本製造情報管理システムを実現するためのモデルについ て述べ，4.でそのモデルに基づいたシステムの実現手法 について述べる. 5. では, コーヒー製造プラントを題材 としたプロトタイプシステムの紹介とその評価について 述べ, 6. ではまとめと今後の展望を述べる.

\section{2. バッチプロセスにおける製造情報管理}

ここでは，バッチプロセスの監視制御システムの標準 化について述べられている参考文献 5)をもとに, バッチ プロセスにおける製造情報管理に要求される機能につい て述べる。

\section{1 バッチプロセスの概要}

製造プロセスは, 製造設備と製造物から構成され, そ の性質によって以下の 3 種類に分類される.

・連続プロセス（continuous process）

ものを切れ目無く連続的に製造する製造プロセス. 製造設備の管理に重点が置かれる.

・組立プロセス (discrete parts manufacturing process)

複数の部品からものを組み上げていく製造プロセス. 製造物の管理に重点が置かれる.

・バッチプロセス（batch process） ものを単位ごとに区切って製造する製造プロセス．製 造設備と製造物の両方に重点を置く必要があり, 相 互の関連も管理する必要がある。
このように，バッチプロセスは連続プロセスと組立プロ セスの両方の性質を持ち合わせている.

実際の製造プロセスにおいては，バッチはバッチ番号 などの識別子により，お互いが識別される。しかし，原 材料投入から最終製品になるまで，同じ識別子を持つと は限らない，たとえば，複数のバッチを混ぜ合わせたり， 一つのバッチを複数に小分けしたりするような操作が行 われ，バッチ番号の付け替えが行われることがある。ま た，製造手順も一様ではなく，バッチの品種などによって 製造設備間を移動する順序が変更されたり，実際の製造 結果に基づいて動的に変更されたりすることが多い.

このようなバッチプロセス特有の性質から，その運転 支援や運転管理を行う製造情報管理システムでは，プラ ント内で製造されるバッチを追跡する機能や，バッチに 着目したり製造設備に着目したりしてデー夕を利用でき る機能が必要となる。

\section{2 バッチ製造情報管理への要求}

2.1 で述べたバッチプロセスの性質を考慮して, その 製造情報管理システムには，以下のような機能が要求さ れる。

・設備に備えつけられたセンサなどから周期的にサン プリングして蓄積した状態履歴データと, その設備 により製造された各バッチとの関連を，容易に引き 出すことができる.

・あるバッチがどのような製造手順で，どのような混 合や分離などの操作が行われて製造されたかを容易 に追跡できる.

- 新しい品種の追加による製造手順の変更や, 新しい 製造設備の追加などが容易に行える.

このような要求を満たすバッチ製造情報管理システム を実現するために, 我々は以下のような点に着目する。

・バッチや製造設備などの複数の角度から収集データ を提供できる機構の提供

- 製造手順の変更や, バッチの混合や分割を表現可能 なデータモデルの提供

・実際の製造プロセスの製造に合わせて, データを構 造化する機構の提供

3. では,これらを実現するバッチ製造情報管理モデルに ついて述べる.

\section{3. バッチ製造情報管理モデル}

\section{1 多次元ビュー}

先に述べたとおり，バッチプロセスでは，製造設備か ら周期的に収集された状態履歴と, 製造設備間を移動し て製造されたバッチとの関連を管理する必要がある。本 製造情報管理システムでは, この要求に対して, 収集さ 
れたデータから多次元ビューを生成することにより，操 作員が時間・製造設備・バッチ間の関連を導出可能な情報 を提供する手法をとる。データベースにおけるビュー1) とは，ある形式 (スキーマ) で格納されているデータを 別の形式で表現した仮想的なデータである. バッチプロ セスは, 時間軸上で複数の製造設備間を製造物が移動す るととらえることができる。このバッチプロセスを多面 的にとらえて，各視点から見たときにどのように見える かが，Fig. 1に示した本製造情報管理システムの多次元 ビューの概念である．図中の立方体の中に製造プロセス が入っていると仮定すると，この製造プロセスを三つの 面から見ることができる．まず，上から見た場合，製造 プロセス内の製造物の動き全体を見渡すことができる. つぎに，右側面から見た場合，ある製造設備における各 バッチの製造状況を見ることができる．最後に，左側面 から見た場合，一つのバッチが各製造設備を流れていく 様子を見ることができる．立方体に製造プロセスを格納 した場合，この 3 種類の見方で対象を的確にとらえるこ とができる。

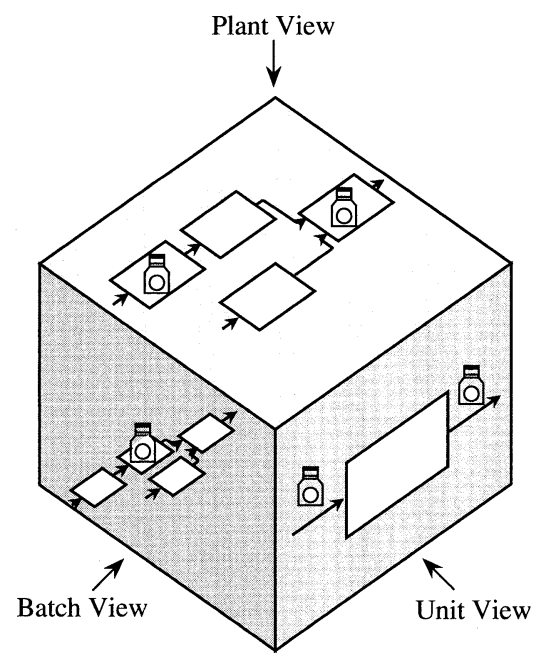

Fig. 1 A concept of the multidimensional views

したがって，本製造情報管理システムでは，バッチプ ロセスから収集されたデー夕を, 以下の三つのビューで 提供する.

・プラントビュー

プラント全体を見渡し,「いつ，どこで，何を」を表 現する。これにより，たとえば，製造プロセスの効 率的な運用計画を立てるための支援を行うことがで きる。

・ユニットビュー
ある製造設備（ユニット）に着目し,「いつ，何が，ど のように」を表現する。これにより，たとえば，製 造設備に不具合が発生した場合の各バッチへの影響 などの分析を支援することができる.

・バッチビュー

あるバッチに着目し,「いつ，どこで，どのように」 を表現する。これにより，たとえば，製造物のある バッチに不具合が見つかった場合, どの製造設備に

問題があったかなどを推測することができる.

以下, 対象となる製造プロセス中に $m$ 個の製造設 備 $U=\left\{u_{1}, u_{2}, \cdots, u_{m}\right\}$ が存在し, $n$ 個のバッチ $B=$ $\left\{b_{1}, b_{2}, \cdots, b_{n}\right\}$ が製造された状態でビューを生成すると 仮定し，各ビューの定義について述べる.

3.1.1 プラントビュー

プラントビューは，指定された時区間において，各製 造設備において製造中であったバッチを表現するものと して，以下のように定義される.

・プラントビュー取得の指定条件は,

一取得時区間 $\left[t_{s}, t_{e}\right)$

一獲得時間幅 $t_{p}$

である。

・プラントビュー $P V$ は,

$P V=\left\{p v_{t_{i}} \mid t_{i}=t_{s}+(i-1) t_{p}, 1 \leq i \leq\left\lceil\left(t_{e}-t_{s}\right) / t_{p}\right\rceil\right\}$

で表される時刻 $t_{i}$ におけるプラントビュー要素 $p v_{t_{i}}$ の集合である。

・時刻 $t_{i}$ におけるプラントビュー要素 $p v_{t_{i}}$ は, 以下 のような属性を含む.

一 時刻印 $t_{i}$.

一時刻 $t_{i}$ において, 各製造設備 $u_{1}, u_{2}, \cdots, u_{m}$ で 製造されていたバッチ $b_{u_{1}}^{t_{i}}, b_{u_{2}}^{t_{i}}, \cdots, b_{u_{m}}^{t_{i}}$.

3.1.2 ユニットビュー

ユニットビューは, 指定された時区間において，指定 された製造設備で製造中であった各バッチの状態履歴を 表現するものとして, 以下のように定義される.

・ユニットビュー取得の指定条件は,

一製造設備 $u \in U$

一取得時区間 $\left[t_{s}, t_{e}\right)$

である。

・ュニットビュー $U V$ は,

$$
U V=\left\{\left.u v_{b_{i}}\right|^{\forall} b_{i} \in B^{\left(u, t_{s}, t_{e}\right)}\right\}
$$

で表される $k$ 個のユニットビュー要素 $u v_{b_{i}}$ の集合 である.ここで, $B^{\left(u, t_{s}, t_{e}\right)}$ は, $B$ の部分集合であ り，時区間 $\left[t_{s}, t_{e}\right)$ に製造設備 $u$ において製造され た $k$ 個のバッチの集合である. 
・各ユニットビュー要素 $u v_{b_{i}}\left(b_{i} \in B^{\left(u, t_{s}, t_{e}\right)}\right)$ は, 以下 の項目を含む。

ーバッチ識別子 $b_{I D}^{b_{i}}$.

一 バッチ $b_{i}$ が製造設備 $u$ において製造された開 始時刻 $t_{s}^{\left(u, b_{i}\right)}$ と終了時刻 $t_{e}^{\left(u, b_{i}\right)}$.

一時区間 $\left[t_{s}^{\left(u, b_{i}\right)}, t_{e}^{\left(u, b_{i}\right)}\right)$ における製造設備 $u$ か

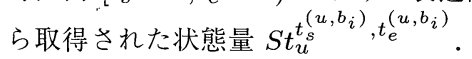

3.1.3 バッチビュー

バッチビューは, 指定されたバッチが経由してきた各 製造設備における状態履歴を表現するものとして, 以下 のように定義される。

・バッチビュー取得の指定条件は，

ー バッチ $b \in B$

である。一般に, ここで指定されるバッチは, 最終 製品に関するバッチとする.

・バッチ $b$ から導出可能な $k$ 個のバッチを, $B^{b}=$ $\left\{b_{1}^{b}, b_{2}^{b}, \cdots, b_{k}^{b}\right\}$ とする.ここで, 導出可能なバッチ とは，製造過程において，バッチの混合や分割が行 われた場合, 混合元や分割先を導出したバッチを再 帰的に求めたものをいう.

・バッチビュー $B V$ は,

$$
B V=\left\{\left.b v_{u_{i}^{b}}\right|^{\forall} u_{i}^{b} \in U^{b}\right\}
$$

で表わされる $l$ 個のバッチビュー要素 $b v_{u_{i}^{b}}$ の集合 である.ここで, $U^{b}$ は, $B^{b}$ 中の少なくとも一つの バッチが経由した製造設備の集合である.

・バッチビュー要素 $b v_{u_{i}^{b}}$ は, 以下のデータを含む.

一製造設備識別子 $u_{I D}^{u_{i}^{b}}$.

- $B^{b}$ 中のバッチのうち, $u_{i}^{b}$ を経由してきた $h$ 個 のバッチ $b_{1}^{\left(b, u_{i}^{b}\right)}, b_{2}^{\left(b, u_{i}^{b}\right)}, \cdots, b_{h}^{\left(b, u_{i}^{b}\right)}$ のそれぞれに 対するユニットビュー要素 $u v_{b_{q}^{\left(b, u_{i}^{b}\right)}}(1 \leq q \leq h)$.

\section{2 製造情報管理データモデル}

3.1 で述べたビューを生成するには，製造設備間のバッ チの動きを検知することにより追跡し，その履歴を蓄積 する必要がある，先に述べたとおり，製造物であるバッ チは，製造が進むに従って製造プロセス内の製造設備間 を移動する。また，最終製造物が製造されるまでに，複 数のバッチが混合されたり, 一つのバッチが複数に分割 されたりする。このようなバッチプロセス特有の製造状 況を計算機中に表現するために, 対象の設備やバッチを 一つ一つの物とみなし，それぞれの状態とその物で行う 処理をカプセル化できるオブジェクト指向データモデル を採用する。

3.2.1 オブジェクト型

バッチ追跡機構のためのオブジェクトとしては, 以下 のようなものが定義される.
・トレンドオブジェクト

製造設備から獲得されたデー夕を時系列として扱う ためのオブジェクトであり, 各製造設備における状 態履歴を時系列的に表現する。

・イベントオブジェクト

製造プロセス内の状態変化を扱うためのオブジェク トであり，製造プロセス内でのバッチの動きを通知 するのに用いられる。

・バッチオブジェクト

製造プロセス内で製造される各バッチに対応するオ ブジェクトであり, 以下のような属性を持つ.

ーバッチ識別子 (バッチ番号)

一各製造設備に対する処理開始時刻, 処理終了時刻

一混合されたり分割された場合の, 元バッチに対 するバッチオブジェクトへのリンク

・製造設備（ユニット）オブジェクト

製造プロセス内の各製造設備に対応するオブジェク トであり, 製造設備名などの固定情報の他に, 以下 のような属性を持つ.

一処理中バッチ

現在，その製造設備で製造中のバッチに対する バッチオブジェクトへのリンク.

一処理済バッチ その製造設備で製造され，次の製造設備へ渡さ れるのを待っているバッチに対するバッチオブ ジェクトへのリンク.

ートレンドデータ

その製造設備から獲得された状態量を時系列と して表現したトレンドオブジェクトへのリンク.

\subsection{2 データ構造}

3.2.1で述べた各オブジェクトは，Fig. 2に示すように 構造化される．製造設備オブジェクトには，その時点で 製造中のバッチに対するバッチオブジェクトがリンクで つながれる，イベントオブジェクトは，製造プロセス内 のバッチの動きに対して, それを各製造設備オブジェク トに対して報告する。また，バッチの混合や分割が行わ れた場合は，バッチオブジェクト間でリンクが張られる.

このようなデータ構造を採ることで，実際の製造プロ セス内のバッチの動きを仮想的に再現できる.

\section{3 能動機構によるバッチの追跡}

3.2 で述べた製造情報管理データモデルをとった場合， 実際の製造プロセス内でのバッチの動きに合わせて，バッ チオブジェクトを製造設備オブジェクト間で移動させる 必要がある。

データベース中，あるいは，外界で発生した事象に対 して処理を起動するための枠組みとしては, 能動機構 2 ) 


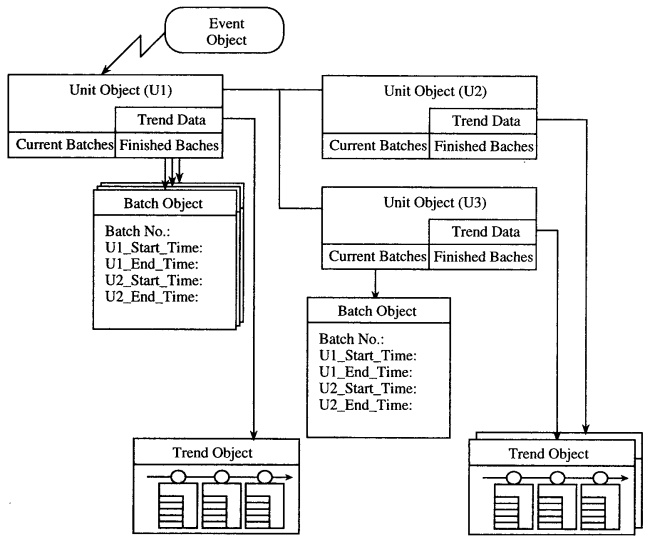

Fig. 2 Data organization for the batch tracing mechanism

が知られている。能動機構は ECA 機構とも呼ばれ，あ る事象 (event) が発生したとき, 条件 (condition) を評 価し，満たしていれば対応する動作 (action) を起動する というものである．製造プロセス内では，様々な事象が 発生し得るが, 本製造情報管理システムでは, バッチの 動きを事象として検知し，それをバッチ追跡に用いる。

バッチは, 以下のようにして能動機構により追跡され, データベース中に蓄積される．

・ある製造設備において製造開始の事象が発生したと

き，前工程からバッチオブジェクトを取得する.

・ある製造設備において製造終了の事象が発生したと

き, 自工程で処理中のバッチオブジェクトを処理済 とし，次工程へ渡す準備をする。

また, バッチの混合や分割を管理するために, 製造設 備を Fig. 3 に示す 5 種類に分類する。

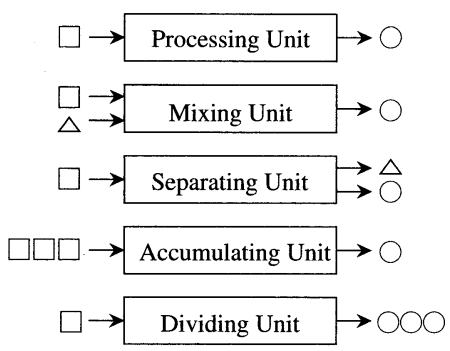

Fig. 3 Unit primitives for the batch tracing mechanism

・加工ユニット

一つのバッチを受取り，一つのバッチを受渡す.

・混合ユニット

異なる種類の複数のバッチを受取り，一つのバッチ
を受渡す。

・分離ユニット

一つのバッチを受取り, 異なる種類の複数のバッチ を受渡す。

・蓄積ユニット

同じ種類の複数のバッチを受取り, 一つのバッチを 受渡す。

・分割ユニット

一つのバッチを受取り, 同じ種類の複数のバッチを 受渡す。

製造設備オブジェクトは，このような分類に基づいて バッチオブジェクト間のリンクを実際の製造プロセスの 進行に合わせて生成する。これにより，多次元ビューを 生成する際に必要なバッチのプラント内での軌跡が追跡 可能となる.

\section{4. バッチ製造情報管理データベースの実現}

\section{1 システム構成}

筆者らはすでに，プラント監視・制御システムを実現す るための基盤として, プラントから実時間性を保証してデ 一夕を獲得・蓄積する Real-Time Data Server (RTDS $)^{3)}$ と，RTDSによって収集されたデータをオブジェクトと して構造化し，アプリケーションに提供する Real-Time View Server (RTVS $)^{4)}$ 開発している。このような構 成とすることにより，製造プロセスからデー夕を確実に 獲得してくることが要求される実時間処理と, その獲得 したデータをバッチプロセスにおける物の流れと関連付 けた製造情報として操作員に提供する非実時間的な処理 を両立させることができる。

Fig. 4に，本製造情報管理システムの全体構成を示す. 製造プロセスには, センサやアクチュエータ, コントロー ラなどが設置され，それらが実時間性を保証した制御系 ネットワークで接続されている. RTDS は,この制御系 ネットワークからデータの獲得およびディスクへの格納 を, 実時間性を確保して行う. また, 獲得したデータから プラント内の状態変化を検知し, 事象として情報系ネット ワーク側へ提供する. RTVSは，一般的なオブジェクト指 向データベースが提供している永続オブジェクトに加え て, RTDSにより提供されるプラント内のデータを，仮 想的にオブジェクトとして扱うことのできるデータベー スサーバである．RTDSにより提供されるプラント内の データは，時間によって絶えず変化するため，それを仮 想的なオブジェクトとして提供するには，その時間的な 性質を考慮する必要があるが，RTVSでは，それを時間 的正当性という概念を用いてデー夕の時間的な正しさを 確保している. なお, RTDS およびRTVSの詳細は, 本 


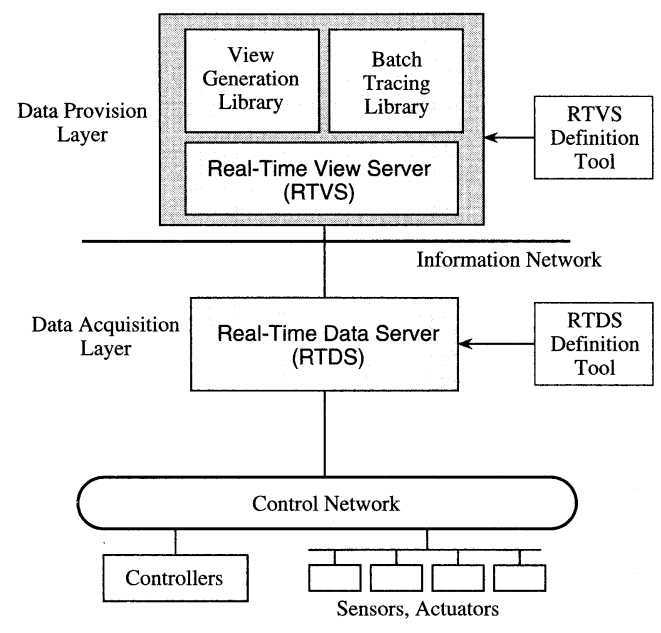

Fig. 4 The architecture of the manufacturing management system

論文の趣旨を超えるので，ここでは省略する.

RTDS およびRTVS は，バッチプロセスに特化したも のでなく，プラントシステムに対して汎用的に用いるこ とができるが，バッチプロセスにおける製造物の流れや， デー夕提供の形態を管理するために, RTVS 上に, 3.1 で述べた三つのビューを生成するビュー生成ライブラリ, および, 3.3で述ベたバッチの追跡を行うバッチ追跡ライ ブラリの二つのライブラリを構築している.

また，対象プラントごとに異なるプラントからの収集 データや, 設備構成, バッチの流れ等を GUI（図的利用者 インターフェイス) で定義可能な RTDS 定義ツール，お よび，RTVS 定義ツールを提供している。これらのッー ルでは，以下のものが定義される.

(1) RTDS 定義ツール

・プラント内の各センサ等からのデータが格納 されている制御系ネットワーク内でのアドレ ス割付けと，それをRTDSに取り込む際の収 集周期やデー夕構造.

- RTDS内に格納しているデータを上位系（本 システムの場合は RTVS）に提供する際のデ 一夕構造.

・バッチの動きなどのイベントを検出するため の条件と，その際に同時に通知されるべきデ 一夕.

(2) RTVS 定義ツール

・プラント内の製造設備の構成.

・プラント内で製造されるバッチ.

・バッチの製造設備間の移動条件（移動を検出 するイベント, 移動元・移動先の製造設備等).
これらの定義情報に従って, 各定義ツールはそれぞれ， RTDSおよびRTVS のソースコードを自動的に出力する （実際には，対象プラントに依存する部分のみを生成す る).これをコンパイル・リンクすることによって, 対象 プラントごとにカスタマイズされたバッチ製造情報管理 システムが構築される.

\section{2 ビュ一生成ライブラリの実現}

4.2.1 プラントビュー

Fig. 5に, プラントビューの構造を示す. 各時刻に対し て，各製造設備で製造中であったバッチが対応付けられ ている.

\begin{tabular}{|c|c|c|c|c|}
\hline Time & $u_{1}$ & $u_{2}$ & $\cdots$ & $u_{m}$ \\
\hline \hline$t_{s}$ & $b_{u_{1}}^{t_{1}}$ & $b_{u_{2}}^{t_{1}}$ & & $b_{u_{m}}^{t_{1}}$ \\
\hline$t_{s}+t_{p}$ & $b_{u_{1}}^{t_{2}}$ & $b_{u_{2}}^{t_{2}}$ & & $b_{u_{m}}^{t_{2}}$ \\
\hline & & & & \\
\hline$t_{s}+(i-1) t_{p}$ & $b_{u_{1}}^{t_{i_{1}}}$ & $b_{u_{2}}^{t_{i}}$ & & $b_{u_{m}}^{t_{i}}$ \\
\hline & & & & \\
\hline$t_{s}+(l-1) t_{p}$ & $b_{u_{1}}^{t_{l}}$ & $b_{u_{2}}^{t_{l}}$ & & $b_{t_{i}}^{t_{l}}$ \\
\hline
\end{tabular}

Fig. 5 Structure of the Plant View

プラントビュー取得条件として指定された取得時区間 $\left[t_{s}, t_{e}\right)$, および, 取得時間幅 $t_{p}$ から得られる各時刻,

$$
t_{i}=t_{s}+(i-1) t_{p}\left(1 \leq i \leq\left\lceil\left(t_{e}-t_{s}\right) / t_{p}\right\rceil\right)
$$

および，各製造設備 $u_{j}(1 \leq j \leq m)$ に対して，以下の手 順により，製造設備 $u_{j}$ 上で時刻 $t_{i}$ において製造されて いたバッチ $b_{u_{j}}^{t_{i}}$ を得る.

$$
\begin{aligned}
& b_{u_{j}}^{t_{i}}=N U L L \\
& \text { for }\left(b=b_{1}, b_{2}, \cdots, b_{n}\right)\{ \\
& \quad \text { if }\left(b . u_{j-s t a r t} \leq t_{i}<b . u_{j \_} \text {end }\right)\{ \\
& \quad b_{u_{j}}^{t_{i}}=\mathrm{b} \\
& \quad\} \\
& \}
\end{aligned}
$$

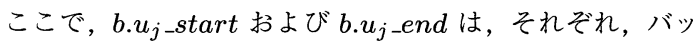
チ $b$ に対するバッチオブジェクトに格納された製造設備 $u_{j}$ における開始時刻, 終了時刻である.これを, すべて の $u_{j}$ ，および，すべての $t_{i}$ に対して行うことで，プラ ントビューが生成される.

\subsection{2 ユニットビュー}

ユニットビューの構造を, Fig. 6に示す. ユニットビュー では，指定された時区間 $\left[t_{s}, t_{e}\right)$ 中に製造設備 $u$ におい て製造された各バッチに対して，そのバッチに関する情 報，および，そのバッチを製造していたときの $u$ の状態 履歴が提供される.

ユニットビュー取得条件により指定された時区間 $\left[t_{s}, t_{e}\right)$ に製造設備 $u$ において製造されたバッチの集合 $B^{\left(u, t_{s}, t_{e}\right)}$ は, 以下の手順で取得される。 


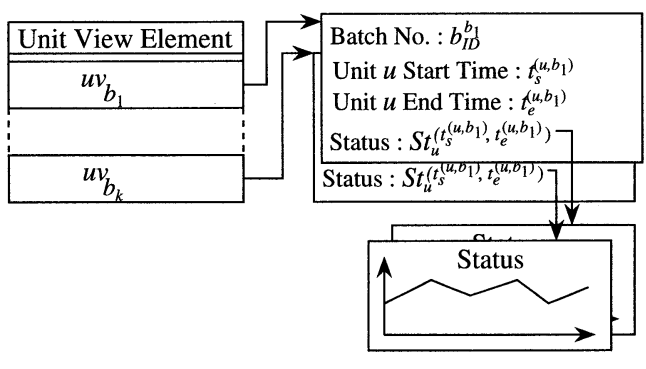

Fig. 6 Structure of the Unit View

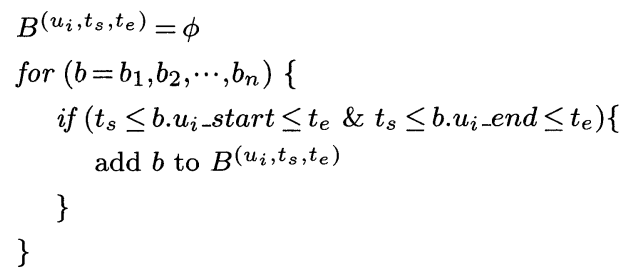

この手順で求めた $B^{\left(u, t_{s}, t_{e}\right)}$ 中の各バッチに対して, その識別子を $u v_{b_{j}}$ の $b_{I D}^{b_{j}}, u$ における開始時刻お よび終了時刻を $u v_{b_{j}}$ の $t_{s}^{\left(u, b_{j}\right)}$ および $t_{e}^{\left(u, b_{j}\right)}$, 時区 間 $\left[t_{s}^{\left(u, b_{j}\right)}, t_{e}^{\left(u, b_{j}\right)}\right)$ における $u$ の状態量を $u v_{b_{j}}$ の

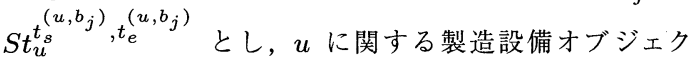
トからリンクされているトレンドオブジェクトから取得 することで，ユニットビューが生成される。

\subsection{3 バッチビュー}

バッチビューの構造を概念的に表したものを, Fig. 7に 示す. 指定されたバッチ $b$, および, それを生成する元と なった中間製造物が経由してきた各製造設備における状 態が提供される.

バッチビューは, 取得条件として指定されたバッチ $b$ か

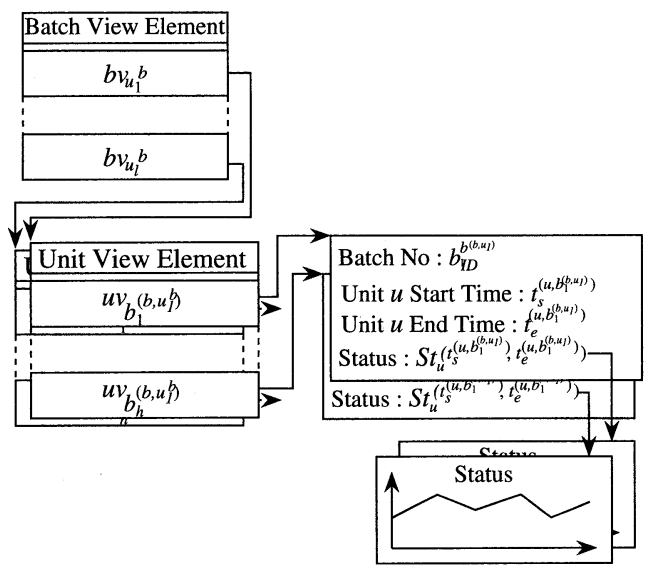

ら導出可能なバッチを求める必要があるが，これは，バッ チオブジェクトに記録されている，元バッチを示すバッ チオブジェクトへのリンクをたどることで求めることが できる、また，バッチがある製造設備を経由したかどう かは，バッチオブジェクト内の各設備に対する入出時刻 が記録されているかどうかで判定できる.

以上でバッチ $b$ に対する各製造設備における導出可能 なバッチが見つかるので，これらのバッチに対して，ユ ニットビュー生成時のユニットビュー要素を構成すること でバッチビューが生成される.

\section{3 バッチ追跡ライブラリの実現}

バッチ追跡機構を実現するには, 製造プロセス内の状 態変化からバッチ移動を RTDSにより検知し, 前述のイ ベントオブジェクトに報告しなければならない。このイ ベントの検知条件は，個々の対象プラントごとに異なる ので，RTDS 定義ツールで行うが，その典型は以下のと おりである。

（1）ある製造設備が稼働中であるかどうかの信号が, 制御系ネットワーク上に周期的に流される。

(2) RTDS のデータ獲得処理は, 内部夕イマにより周 期的に起動される。この内部夕イマによる割り込 みを, ECA 機構の Event とみなす。

(3) RTDS は, 獲得したデー夕を, 前回獲得したデー 夕と比較する。もし, 前回獲得したデー夕の值が 稼働中でなく, 今回獲得したそれが稼働中であっ た場合，バッチがその製造設備に投入されたと判 断する。逆に, 前回獲得したデー夕の值が稼働中 であり，今回獲得したそれが稼働中でなかった場 合，バッチがその製造設備における処理を終えた と判断する。この条件が, ECA 機構の Condition とみなされる。

（4）製造設備の稼働状況が変化し，バッチの移動が検 知されれば，RTDS はそれをバッチ番号や移動元 ／移動先設備などの付随情報と共にRTVSへ転送 する. RTVSはそれをバッチ追跡ライブラリにイ ベントオブジェクトとして提供し，イベントオブ ジェクトは, 対応する製造設備オブジェクト内のメ ソッド（Process_Start, Process_End）を起動し, バッチオブジェクトへの時刻の記録や製造設備オ ブジェクトからのリンクの張り替えなどが行われ る。この一連の動作が, ECA 機構の Action と見 なされる。

製造プロセス内のバッチの動きに対して, 製造設備オ ブジェクトでは以下のメソッドを実行し，バッチの追跡 を行う。

Fig. 7 Structure of the Batch View 


\section{- Process_Start}

イベントオブジェクトにより，その製造設備でのバッ チ製造開始が報告されたとき，このメソッドが起動 され，移動元製造設備の処理済バッチからバッチオ ブジェクトを取得し，バッチオブジェクト内の処理 開始時刻を書き込み，自製造設備オブジェクトの処 理中バッチ属性にリンクする.

- Process_End

イベントオブジェクトにより，その製造設備でのバッ チ製造終了が報告されたとき，このメソッドが起動 され，処理中バッチ属性にリンクされているバッチ オブジェクトに処理終了時刻を書き込み，処理済バッ チ属性にリンクする.

また，何らかの原因によるプラントからのイベントの 通知もれ等によって, 上記のバッチ追跡処理を行う際に 矛盾を発見する場合がある（たとえば，処理中バッチが 存在しないのにProcess_End メソッドが起動された場合 や, 操作員の手動操作によりイベントが検出できなかっ た場合など）。そのような状況に対処するために，バッ チ追跡ライブラリ内から矛盾を発見した場合に呼び出す べき処理を登録する機能を提供している。また，操作員 が直接操作できるプログラムから，バッチ追跡機構内の バッチ追跡状態を変更できる機能も提供している。 これ らの機能を用いて, 対象プラントの計算機内の状態と現 実の状態との一貫性を取るための処理を記述することが できる。

つぎに，バッチの混合や分岐が発生した際のバッチオ ブジェクト間でのリンクは, 製造設備の種類に応じて, 以 下のように実行される.

・製造設備が加工工程の場合は, 何も行わない.

・製造設備が混合工程, あるいは, 蓄積工程の場合は, 混じり合って新しく生成されたバッチに対するバッ チオブジェクトから, 混じり合う元のバッチオブジェ クトへ 1 対多のリンクを張る.

- 製造設備が分離工程, あるいは, 分割工程の場合は, 分岐して新しく生成されたバッチに対するバッチオ ブジェクトから, 分岐する元のバッチオブジェクト

へ多対 1 のリンクを㲀る.

一般に, 加工工程以外では, 入力となったバッチと出力 となったバッチでバッチオブジェクトの型が異なるため, 混合工程と蓄積工程, あるいは, 分離工程と分割工程で は，バッチオブジェクト間のリンクを張るためのメソッ ドの実現が異なる。

\section{5. 適用例と評価}

4. までに述べたバッチ製造情報管理データベースにお ける多次元ビュー生成機構, および, 能動機構によるバッ
チ追跡機構を実現し，コーヒー製造プラントに適用した プロトタイプシステムを紹介する.

\section{1 構成}

本プロトタイプシステムは, Lynx 社の実時間 OSであ る LynxOS 上に構築され, 以下の各サブシステムから構 成される。

\section{・プラントシミュレータ}

コーヒー製造を模擬的に実施し，製造プロセスの状 況をシミュレートする。シミュレート結果は, 共有 メモリ上に書き出される.

- Real-Time Data Server (RTDS)

シミュレータの出力結果を共有メモリから周期的に 獲得し, 時系列データとして格納する。また，バッ チの動きを検知し，RTVSに通知する。

- Real-Time View Server (RTVS)

RTDS から報告されたバッチの動きに対する事象に 基づき, バッチ追跡ライブラリによりバッチの流れ の履歴を管理する。また, ビュー生成ライブラリに より,ビューを生成する。

・データビュア

ビュー生成ライブラリより取得した各ビューを表示 する.

また, Microsoft 社の Windows95 上で動作可能な RTDS 定義ツール, RTVS 定義ツールにより, モデルプ ラントであるコーヒー製造プラントから収集するデータ やプラント内の製造設備やバッチなどの構成を定義し, プ ラントごとにカスタマイズされたシステムが生成される.

\section{2 実行例}

Fig. 8に，コーヒー製造プラントにおけるプラントビ ユーを示す．縦軸に各製造設備である，ロースタ(コー ヒー豆の焙煎)，ミル(コーヒー豆の粉砕）, ブレンダ (コーヒー粉末の混合), ドリッパ(コーヒー液の抽出), ミキサ（クリームとシロップの混合）が並び, 横軸の時 刻に対して製造中であったバッチがバッチ番号を含んだ 四角形で示されている.

Fig. 9は，ドリッパに対するユニットビューの例である. 指定されたある時刻において製造中であった各バッチに 対して，それぞれのバッチを抽出していたときの液温が 示されている.

Fig. 10は，バッチビューの表示例である.あるバッチ に対して，そのバッチがブレンダ, ドリッパ，ミキサの各 製造設備に存在した際の, 湿度や温度などが表示されて いる.なお，本コーヒー製造プラントでは，ミキサで四 つのコーヒー液バッチを蓄積する処理を行っており, 蓄 積された後のバッチから,ブレンダやドリッパにおける 蓄積される前のバッチも導出されている。 


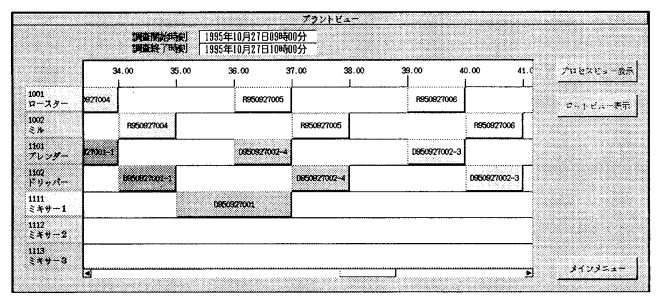

Fig. 8 A screen example of the Plant View

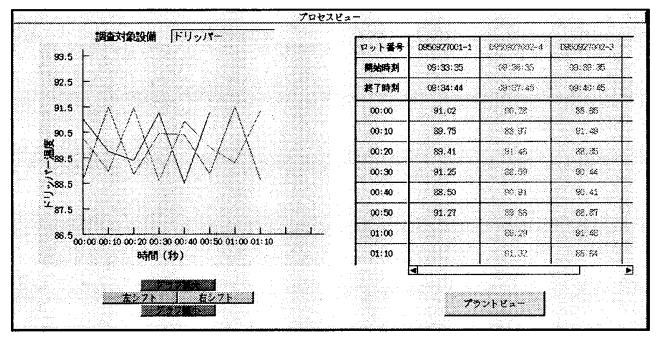

Fig. 9 A screen example of the Unit View

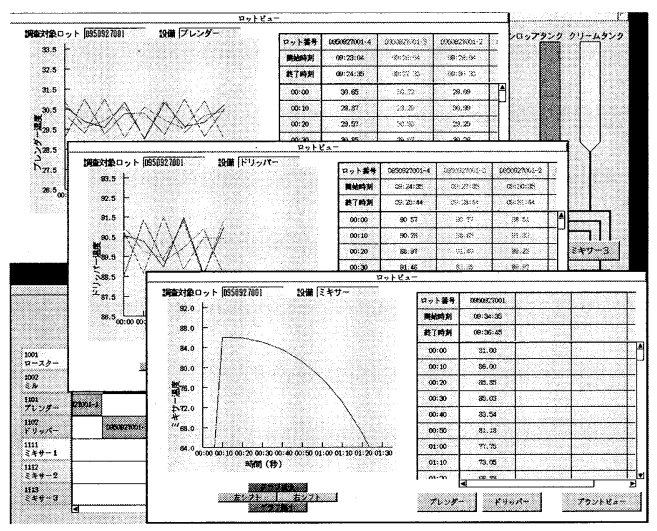

Fig. 10 A screen example of the Batch View

\section{3 評価}

本システムを用いたコーヒー製造プラントへの適用に 要した時間は, RTDSやRTVS にかかわる部分の定義, および，カスタマイズされたシステムの生成を合わせて， わずか数時間程度であった。また，鉄鋼プロセスへの適 用のために評価を行った実際の型鋼製造プロセスを題材 とした場合も，RTDSやRTVSの定義・生成にかかわる 部分は，数日で終えることができた（実際には，画面表 示等のデータベース以外の部分からの出戻りが生じたた め, 全体としては 2 週間程度を要した).

また, Pentium 133MHz を搭載した産業用計算機上で の本システムの性能の目安としては, 状態量を 10 秒ご と, 約 3 分ごとのバッチの投入程度の頻度でデータの収
集を 1 週間行った状態（時系列データとして工程ごとに 6 万データ, 各ロットデータとして 3000 データ程度) での 検索時間は, プラントビューで 1 秒程度, ユニットビュー, および，ロットビューで 2 秒程度であった．実際の製造プ ロセスへの運用時にはギガバイト単位のデー夕量となる が, 二分検索アルゴリズムを用いているので, 十分な応 答性を確保できると考えている.

\section{6. あとがき}

本論文では，バッチ製造情報管理システムの構築の際 に, 対象プラント間で共通に利用可能なソフトウエア階 層を実現するためのバッチ追跡機構, および, デー夕提 供機構のモデルと, その実現について述べた. 本システ ムにより, 対象プラントごとの違いによるソフトウエア の再利用性の無さをなくし, ソフトウエアの生産性向上 を達成することが可能となった。 現在, 本論文で提案し たモデルに基づき, 鉄鋼プラントシステムの開発が進ん でおり, 生産性向上に貢献している。

\section{謝辞}

本研究を進めるにあたり, 有益な御助言を頂きました 京都大学工学部情報工学教室の上林弥彦教授, ならびに, 上林研究室の皆様に感謝いたします。

\section{参考文献}

1) C. J. Date: An Introduction to Database Systems, Addison-Wesley (1990)

2) K. R. Dittrich, S. Gatziu and A. Geppert: The active database management system manifesto: A rulebase of ADBMS features; International Workshop of Rules in Database Systems, pp. 3-17 (1995)

3) 島川, 水沼, 竹垣 : プラント履歴データの実時間獲得・提 供システム; 電子情報通信学会論文誌, D-I, Vol. J78-D-I, No. 8, pp. 798-806 (1995)

4) 高田, 島川, 浅野, 井戸, 竹垣：時間的正当性を考慮したオブ ジェクトモデルに基づくプラント監視向けデータベースシス テムの構築; 電子情報通信学会論文誌, D-I, Vol. J79-D-I, No. 10 , pp. 853-862 (1996)

5) ISA S88.01 Batch Control Standard Part 1: Models and Terminology, Instrument Society of America (1995) 
